\title{
CHEMICAL COMPOSITION AND GEOCHEMICAL FEATURES OF MICAS FROM LAMPROITES OF THE ALDAN SCHIELD, USSR.
}

Vladykin, N.V.

Institute of Geochemistry, Irkutsk, USSR.

The chemical composition and the concentrations of 25 rare elements were studied in 60 mica samples from the Aldan lamproites. They refer to Mg-biotite Fe-phlogopite tetraferriphlogopite type according to the chemical composition. Al deficiency and the heightened $\mathrm{Ti}, \mathrm{Ba}, \mathrm{Cr}$ concentrations are typical of them. $\mathrm{T} \mathrm{e}^{3+}$ occur in the tetrahedral coordination instead of Al. The natural change of rare element concentrations is observed in micas from the early olivine lamproites to the later leucite and sanidine varities. The low concentrations of lithophyle elements and high ones of siderophile elements are common to the micas of lamproites. It indicates their deep mantle genesis. 